\title{
Pembelajaran Interaktif Edu-Game Pengenalan Profesi Berbasis Android Pada Siswa Paud
}

\author{
Muhammad Rais \\ Teknologi Pembelajaran, Fakultas Teknik Universitas Negeri Makassar, Indonesia \\ Email:m.rais@unm.ac.id \\ Muhammad Riska \\ Pedidikan Teknologi Kejuruan, Fakultas Teknik Universitas Negeri Makassar, Indonesia \\ Email: muhammadrbabo@unm.ac.id
}

(Diterima: 01-September-2017; direvisi: 23-Mei-2017; dipublikasikan: 27-Juni-2018)

\begin{abstract}
This research is a second year development research that aims to test the usefulness, accuracy, and feasibility of interactive professional recognition learning application products. The trial subjects were expert groups (learning media and PAUD learning), product user groups (PAUD teachers), and PAUD students. The results showed that application products included in the criteria were very useful, very feasible and very appropriate. This means that the substance of the edu-game profession application that has been developed has met the criteria of useful, proper and appropriate, so that it can be used as a choice of professional learning introduction media for PAUD students. The results of observations of PAUD students during the product user trial stage, obtained information that shows that PAUD students have been able to: 1) find differences in various types of professions, 2) play puzzle games to recognize the profession, and 3 ) recognize the profession through audio messages and pictures. Thus the interactive learning product application of edu-game profession meets the criteria of acceptable (acceptable) which is useful, feasible, and appropriate, and therefore can be used as an alternative choice of learning media that is fun and challenging for PAUD students in introducing the profession
\end{abstract}

Keywords: Interactive Learning; Professional Introduction; Android

\begin{abstract}
Abstrak. Penelitian ini adalah penelitian pengembangan tahun kedua yang bertujuan untuk menguji kegunaan, ketepatan, dan kelayakan produk aplikasi pembelajaran pengenalan profesi yang interaktif. Subjek uji coba adalah kelompok ahli (media pembelajaran dan pembelajaran PAUD), kelompok pengguna produk (guru PAUD), dan siswa PAUD. Hasil penelitian menunjukkan bahwa produk aplikasi termasuk dalam kriteria sangat berguna, sangat layak dan sangat tepat. Artinya substansi dari aplikasi edu-game profesi yang dikembangkan tersebut sudah memenuhi kriteria berguna, layak dan tepat, sehingga dapat digunakan sebagai pilihan media pembelajaran pengenalan bidang profesi pada siswa PAUD. Hasil observasi belajar siswa PAUD selama tahap uji coba pengguna produk, diperoleh informasi yang menunjukkan bahwa siswa PAUD telah dapat: 1) mencari perbedaan berbagai jenis profesi, 2) memainkan permainan puzzle untuk mengenali profesi, dan 3) mengenali profesi melalui pesan audio dan gambar. Dengan demikian produk pembelajaran aplikasi edu-game profesi yang interaktif memenuhi kriteria acceptable (dapat diterima) yaitu berguna, layak, dan tepat, dan karena itu dapat digunakan sebagai salah satu alternatif pilihan media pembelajaran yang menyenangkan dan menantang bagi siswa PAUD dalam mengenalkan bidang profesi.
\end{abstract}

Kata Kunci: Pembelajaran Interaktif; Pengenalan Profesi; Android 


\section{PENDAHULUAN}

Mengenalkan berbagai jenis profesi pada siswa PAUD melalui aplikasi edu-game hendaknya dibangun atas rasa keinginan anak untuk mengetahui konsep dasar dari suatu gambar profesi. Memunculkan gambar profesi dalam aplikasi edu-game memberikan rasa ingin tahu bagi siswa mengenal lebih jauh konsep yang dikandung dalam setiap bidang profesi. Penelitian tahun pertama terhadap kemungkinan penerapan aplikasi edu-game pada siswa dan guru PAUD memberikan informasi berarti bahwa produk yang dikembangkan telah menekankan pada aspek permainan seperti permainan puzzle, permainan mencocokkan gambar, dan menemukan perbedaan gambar profesi. Permainan ini telah mensiratkan informasi konsep terkait profesi sehari-hari menjadikan siswa PAUD mudah menyerap informasi jenis profesi.

Pengertian game menurut Nilwan (2009) adalah aktivitas terstruktur atau semi-terstruktur yang biasanya dilakukan untuk bersenang-senang dan kadang juga digunakan sebagai alat pembelajaran. Menurut Clark (2006) game adalah kegiatan yang melibatkan keputusan pemain, berupaya mencapai tujuan dengan dibatasi oleh konteks tertentu. Sedangkan menurut Yatmo, (2013) game adalah sesuatu yang memiliki "akhir dan cara mencapainya": artinya ada tujuan, hasil dan serangkaian peraturan untuk mencapai keduanya. Selanjutnya, Yatmo (2013) mendefinisikan game sebagai aktivitas yang mencakup karakteristik berikut: fun (bebas bermain adalah pilihan bukan kewajiban), separate (terpisah), uncertain(tak menentu), nonproductive (tak produktif), governed by rules (diatur oleh aturan), fictitious (samaran). Dengan demikian game dapat dikonsepsi sebagai sebuah interaktif, aktivitas yang berpusat pada sebuah pencapaian, ada pelaku aktif (player), ada pelaku pasif (NPC).

Game dalam penelitian ini termasuk dalam $P C$ merupakan permainan yang memberikan pembelajaran yang menyenangkan dan memotivasi dengan cara meningkatkan rasa ingin tahunya, untuk lebih memahami dan mencintai suatu profesi dan menentukan minat dalam pilihan karirnya. Perangkat lunak game akan memberikan output yang berupa gambar atau teks yang ditampilkan melalui media (televise, computer, telpon seluler) kemudian pemain memberika input berupa perintah yang disalurkan melalui perangkat keras permainan tersebut untuk ditampilkan kepada media.
Berdasarkan genre game, game yang diteliti berjenis game edukasi yang yang menciptakan kemampuan pada lingkungan game yang diberikan sebagai alat bantu untuk memotivasi atau membantu siswa untuk melalui prosedur game secara teliti guna mengembangkan kemampuan dan minat anak.

Penelitian pengembangan media edu-game yang memanfaatkan teknologi informasi komputer berbasis android sebagai media dalam mengarahkan minat karir siswa (sesuai rencana target capaian tahunan), akan difokuskan pada finalisasi produk. Validasi produk pada kelompok pengguna dan ahli menjadikan produk penelitian mendekati nilai guna (usefully) dan mudah dipahami siswa (friendly). Dengan demikian, maka rancangan model aplikasi edugame ini akan menekankan pada aspek model penciptaan suasana permainan yang dikemas dalam bentuk bimbingan pengenalan jenis profesi yang disesuaikan dengan kemampuan dan kognisi peserta didik agar mampu terus memainkan dan memenangkan permainan (Hamari et al, 2016). Makna memenangkan permainan dalam edu-game menunjukkan bahwa siswa telah mengerti makna setiap profesi yang dimainkannya.

Bermain merupakan kegiatan menyenangkan yang dilaksanakan untuk memenuhi kepentingan kegiatan itu sendiri. Bermain menurut Santrock (2002) memberikan kesempatan bagi anak untuk melakukan penyesuaian diri dengan lingkungan dan menolong anak menguasai kecemasan dan konflik. Dengan bermain, banyak fungsi-fungsi kejiwaan dan kepribadian yang dapat dikembangkan. Hal ini disebabkan karena di dalam aktivitas bermain banyak kejadiankejadian yang melibatkan keaktifan kejiwaan dan kepribadian pesertanya Simatupang (2005). Dengan bermain, menjadikan seluruh aspek seperti fisik-motorik, kognitif, bahasa, emosi, sosial, berimajinasi, beraktivitas, etika dan moral yang melekat dalam diri anak akan dapat dikembangan sebagai media mengkonstruksi tumbuh kembang anak, termasuk aspek kemampuan kognitif anak.

Melalui proses bermain dengan mulai mengenalkan profesi kepada anak tidak seperti apa yang terjadi selama ini bahwa anak hanya mengenal beberapa jenis profesi yang menjadi favorit anak usia dini, yang kemungkinan besar dikarenakan doktrin orang tua sehingga yang dikenalkan hanya profesi strategis yang dianggap oleh orang tua sebagai suatu profesi 
penghasil uang (anggapan orang tua) tanpa memikirkan berapa biaya yang harus dikeluarkan serta kemampuan apa yang harus menjadi bekal anak untuk bisa menjadi seorang dokter, polisi, tentara, pilot dan angkatan laut (profesi favorit).

Belajar interaktif merupakan bentuk pembelajaran yang mendorong sikap partisipatif dan komunikatif yang menyenangkan. Penggunaan aplikasi edu-game sebagai media pembelajaran interaktif berbasis android adalah bersifat mobile. Pembelajaran melalui teknologi mobile memungkinkan setiap orang dapat mengakses informasi dan materi pembelajaran kapan dan di mana saja dengan ciri utama yang dinamis dalam penggunaannya melalui perangkat yang terkoneksi seperti mobile phone dan smart phone (Ally, 2009: Woodill, 2010; Darmawan, 2012). Menurut Istiyanto (2013) sistem operasi android memiliki popularitas berupa: kecepatan, produktivitas, kreatifitas desain, fleksibilitas, dan keandalan. Selain itu, aspek android memiliki platform mobile masa depan dengan ciri yang lengkap, terbuka dan bebas (Safaat, 2012).

Dengan demikian tujuan penelitian ini adalah menghasilkan perangkat pembelajaran berupa media pembelajaran profesi menggunakan HP android. Melalui aplikasi android bernama Game Edukasi Profesi untuk PAUD, guru dan siswa dapat saling berinteraksi, bermain bersama memanfaatkan penggunaaan HP sebagai media untuk membelajarkan berbagai jenis pekerjaan. Selain itu, diperoleh bentuk pembelajaran yang bersifat edu-game yang mengedukasi siswa melalui: 1) menunjuk gambar (dari kata suara gambar ke objek), 2) menu mencocokan profesi dengan peralatan (gambar dipilih berdasarkan jenis profesi), 3) menu membedakan gambar profesi (find different), 4) menu bermain puzzle, dan 5) menu konsep yang menjelaskan pengertian dari setiap profesi (rekognisi) melalui suara konsep. Menu-menu ini akan ditampilkan langsung dalam aplikasi HP berbasis android yang dapat langsung dimainkan oleh anak melalui pendampingan guru di kelas

\section{METODE PENELITIAN}

Penelitian ini merupakan penelitian
pengembangan yang dirancang untuk
menghasilkan produk. Penelitian pengembangan
menggunakan model ADDIE yang dikembangkan
oleh Gustafson dan Branch (2002) dengan lima
tahapan utama, yaitu Analyze, Design, Develop,

Implement, and Evaluate. Tahap analisis dan desain telah dilakukan pada tahun pertama (2017) dan tahap pengembangan dilakukan pada tahun 2018.

Prosedur pengembangan diuraikan sebagai berikut: Tahap pertama (tahun 2017) telah dilakukan analisis kebutuhan melalui kajian pustaka yang berkaitan dengan topik penelitian, kajian penelitian yang relevan dengan bidang yang diteliti, selanjutnya telah dilakukan studi lapangan yang berkaitan dengan topik penelitian. Model pengembangan Borg \& Gall (2003) mengembangkan daftar kriteria yang dapat dipertimbangkan dalam phase analisis kebutuhan, antara lain 1) apakah produk yang diusulkan sudah disesuaikan dengan kebutuhan, 2) apakah tersedia kajian yang cukup yang memungkinkan produk ini dibangun, 3) apakah tersedia sumber daya manusia, 4) dapatkah produk dikembangkan dalam suatu waktu yang layak Tahap kedua adalah mendesain aplikasi edu-game profesi dengan menggunakaan desain pengembangan Gustafson dan Branch (2002) mulai dari tahap analisis hingga tahap evaluasi. Tahap selanjutnya adalah pengembangan produk untuk menghasilkan produk berupa model aplikasi edu-game profesi.

Tahap berikutnya adalah uji coba terhadap produk yang dikembangkan. Uji coba dilakukan oleh pakar yang ahli dibidangnya, dalam hal ini adalah uji ahli materi PAUD dan ahli media pembelajaran. Produk yang sudah tervalidasi, selanjutnya diuji cobakan pada kelompok pengguna produk, dalam hal ini adalah guru PAUD. Hasil uji coba memungkinkan untuk direvisi, lalu dianalisis hingga ditemukan produk akhir yang sudah memenuhi kriteria berguna, layak, dan tepat.

Subjek penelitian pada studi validasi produk adalah melibatkan kelompok ahli media pembelajaran dan ahli isi materi PAUD. Subjek selanjutnya adalah kelompok pengguna produk dari guru PAUD, sedangkan siswa PAUD dicobakan sebagai pengguna yang penilaiannya dilakukan melalui observasi terhadap tingkat penerimaannya dalam mengikuti pengenalan bidang profesi. Observasi terhadap siswa PAUD fokus pada 1) minat mengikuti edu-game profesi, 2) motivasi mengikuti edu-game profesi, 3) kesenangan mengikuti instruksi guru, 4) kemudahan dalam mengerjakan edu-game profesi, 5) kesukaan terhadap permainan aplikasi edu-game profesi, dan 6) kesan ingatan terhadap bidang profesi. 
Analisis data ditekankan pada aspek deskripsi hasil respon validator, dan hasil uji coba pada kelompok pengguna produk (guru PAUD), sedangkan terhadap siswa PAUD dinilai dari hasil pengamatan dalam bermain edu-game dalam bentuk skor rata-rata.

\section{HASIL DAN PEMBAHASAN}

Penelitian ini melibatkan dua orang ahli, yaitu ahli isi bidang PAUD dan ahli media pembelajaran berbasis komputer. Kedua ahli digunakan untuk menilai akseptabilitas dari isi aplikasi edu-game profesi yang dikembangkan. Para ahli diminta untuk menilai tingkat akseptabilitas buku panduan dan aplikasi edugame profesi, yaitu meliputi: kegunaan, kelayakan dan ketepatan dengan bahan treatment yang telah disiapkan sebelumnya. Pendekatan dalam penilaian ahli adalah secara kuantitatif dan kualitatif, sehingga data yang dihasilkan dari kedua ahli adalah data dalam bentuk kuantitatif dan data kualitatif.

Penilaian yang diperoleh dengan penyebaran angket penilaian kepada para ahli yaitu ahli PAUD dan ahli psikologi pendidikan. Untuk mendapatkan penilaian dari ahli tentang akseptabilitas dilihat dari tiga aspek yaitu, kegunaan, kelayakan, dan ketepatan aplikasi edugame profesi. Adapun hasil penilaian akseptabilitas yang meliputi tiga aspek, yaitu: kegunaan, kelayakan dan ketepatan. Ketiga aspek akseptabilitas akan dinilai oleh kedua ahli dengan menggunakan angket penilaiaan akseptabilitas. Penilaian ahli merupakan tahapan uji coba kelompok ahli sebagai upaya memperoleh panduan yang memiliki keberterimaan yang baik bagi pengguna nantinya. Uji coba dilakukan dengan cara memberikan angket penilaian kepada ahli dan kemudian diikuti dengan diskusi.

Hasil uji coba penilaian terhadap aplikasi edu-game profesi oleh ahli berturut-turut disajikan sebagai berikut.

\section{Aspek Kegunaan}

Indikator yang digunakan untuk menjelaskan kegunaan aplikasi edu-game profesi adalah dengan dua indikator yaitu: indikator pengguna produk dan indikator persyaratan kemampuan/keterampilan yang diperlukan bagi pengguna produk. Hasil penilaian ahli menunjukkan bahwa untuk indikator kebernilaian pengguna produk yang terdiri atas item-item seperti, faedah aplikasi edu-game profesi bagi guru dan siswa PAUD, aplikasi edu-game profesi bagi guru dan siswa PAUD, manfaat aplikasi edu-game profesi bagi guru dan siswa PAUD dalam mengenalkan berbagai jenis profesi. Kedua ahli sepakat bahwa aplikasi ini sangat berguna dalam mengenalkan profesi pada siswa PAUD dengan memberi skor tinggi yaitu empat, artinya bahwa aplikasi edu-game profesi yang dikembangkan ini sangat berguna bila diterapkan pada PAUD dalam mengenalkan profesi. Hasil penilaian ahli dalam melihat aspek kegunaan aplikasi disajikan dalam tabel 1 sebagai berikut.

Tabel 1. Penilaian Ahli Tentang Kegunaan Aplikasi Edu-Game Profesi

\begin{tabular}{|c|c|c|c|}
\hline \multirow{2}{*}{\multicolumn{2}{|c|}{ Butir Pertanyaan }} & \multicolumn{2}{|c|}{ Penilaian } \\
\hline & & Ahli 1 & Ahli 2 \\
\hline 1. & $\begin{array}{l}\text { Faedah aplikasi edu-game } \\
\text { profesi dalam mengenalkan } \\
\text { profesi. }\end{array}$ & 4 & 4 \\
\hline 2. & $\begin{array}{l}\text { Pentingnya aplikasi edu- } \\
\text { game profesi dalam } \\
\text { mengenalkan profesi. }\end{array}$ & 4 & 4 \\
\hline 3. & $\begin{array}{l}\text { Manfaat aplikasi edu-game } \\
\text { profesi dalam mengenalkan } \\
\text { profesi. }\end{array}$ & 4 & 4 \\
\hline 4. & $\begin{array}{l}\text { Perlunya aplikasi edu-game } \\
\text { profesi dalam mengenalkan } \\
\text { profesi. }\end{array}$ & 4 & 4 \\
\hline 5. & $\begin{array}{l}\text { Perlunya guru memiliki } \\
\text { pengetahuan teknologi } \\
\text { android dalam menjalankan } \\
\text { aplikasi edu-game profesi. }\end{array}$ & 4 & 3 \\
\hline 6. & $\begin{array}{l}\text { Perlunya guru memahami } \\
\text { buku panduan menjalankan } \\
\text { aplikasi aplikasi edu-game } \\
\text { profesi dalam mengenalkan } \\
\text { profesi }\end{array}$ & 4 & 4 \\
\hline 7. & $\begin{array}{l}\text { Tingkat kesulitan aplikasi } \\
\text { edu-game profesi dalam } \\
\text { mengenalkan profesi }\end{array}$ & 4 & 4 \\
\hline 8. & $\begin{array}{l}\text { Tingkat kegunaan aplikasi } \\
\text { edu-game profesi dalam } \\
\text { mengenalkan profesi }\end{array}$ & 4 & 4 \\
\hline & Jumlah Skor & 32 & 31 \\
\hline & Rerata Skor & 4 & 3.875 \\
\hline & Kategori & $\begin{array}{c}\text { Sangat } \\
\text { berguna }\end{array}$ & $\begin{array}{c}\text { Sangat } \\
\text { berguna }\end{array}$ \\
\hline
\end{tabular}

Berdasarkan tabel 1 diperoleh hasil penilaian ahli PAUD dan ahli media pembelajaran. Kedua ahli memberikan penilaian pada aspek kegunaan dari aplikasi ini dengan 
skor yang tinggi, yaitu ahli 1 rata-rata memberi skor 4 pada sebagian besar item pertanyaan yang diberikan pada aspek kegunaan dari aplikasi, dan ahli 2 memberi skor rata-rata 3.875 mendekati 4 . Dengan demikian aplikasi edu-game profesi ini dikategorikan sangat berguna dan dapat digunakan sebagai salah satu pilihan media pembelajaran profesi pada siswa PAUD.

\section{Aspek Kelayakan}

Indikator yang digunakan untuk menunjukan kelayakan aplikasi edu-game profesi sebagai media pembelajaran mengenalkan berbagai jenis profesi. Prosedur kepraktisan menyangkut kepraktisan petunjuk penggunaan, sistem navigasi, desain gambar profesi, kemudahan permainan pemberian motivasi, variasi warna dan bidang profesi. Berkenaan dengan kepraktisan langkah-langkah dalam menjalankan aplikasi edugame profesi, kedua ahli menyatakan memenuhi aspek kepraktisan.

Indikator kelayakan aplikasi edu-game profesi yang akan diuraikan selanjutnya adalah keefektifan tenaga, waktu dan biaya. Menyangkut tenaga yang dibutuhkan untuk menjalankan aplikasi yang dirancang, kedua ahli berpendapat simpel, cukup dengan menginstall aplikasi dan dijalankan. Selanjutnya, menyangkut besarnya jumlah waktu yang dibutuhkan untuk menjalankan sistem navigasi antar ketiga jenis permainan, ahli media pembelajaran menyatakan bahwa jumlah waktu yang dibutuhkan cukup efektif dan efisien dalam mengenalkan profesi pada siswa PAUD. Pendapat yang sama dikatakan oleh ahli PAUD, isi dari aplikasi edu-game profesi cukup sesuai dengan kompetensi yang dikenalkan pada siswa PAUD. Selanjutnya menyangkut jumlah biaya yang dibutuhkan agar dapat menggunakan aplikasi edu-game profesi sangat murah. Cukup menginstall aplikasi di Play Store bagi pengguna android aplikasi ini dapat diperoleh. Dengan demikian dalam hal tenaga, penggunaan aplikasi edu-game profesi tidak terlalu membutuhkan tenaga dalam jumlah banyak, bahkan seperti biasa saja di kelas sejumlah guru PAUD di kelas. Dalam hal biaya, aplikasi sangat murah karena bersifat free bagi siapa saja yang akan memanfaatkannya. Cukup menginstall dari play store. Dalam hal waktu, justru pelaksanaan pengenalan profesi pada siswa PAUD dengan menggunakan aplikasi android di handphone menjadi menjadi sangat efektif dan efisien, karena suasananya menyenangkan bagi siswa menggunakan hand phone. Untuk lebih jelasnya hasil tabulasi aspek kelayakan disajikan pada tabel 2 di bawah ini.
Tabel 2. Penilaian Ahli Tentang Kelayakan Aplikasi Edu-Game Profesi

\begin{tabular}{|c|c|c|c|}
\hline \multicolumn{2}{|r|}{ Butir Pertanyaan } & \multicolumn{2}{|c|}{ Penilaian } \\
\hline & & Ahli 1 & Ahli 2 \\
\hline & $\begin{array}{l}\text { Aplikasi edu-game profesi } \\
\text { mendorong rasa ingin tahu } \\
\text { bagi siswa PAUD dalam } \\
\text { mengenal berbagai bidang } \\
\text { profesi }\end{array}$ & 4 & 4 \\
\hline 2. & $\begin{array}{l}\text { Aplikasi edu-game profesi } \\
\text { mendorong suasana belajar } \\
\text { menyenangkan bagi siswa } \\
\text { PAUD dalam mengenal } \\
\text { berbagai bidang profesi }\end{array}$ & 4 & 4 \\
\hline 3. & $\begin{array}{l}\text { Aplikasi edu-game profesi } \\
\text { memiliki kepraktisan } \\
\text { (kemudahan } \\
\text { menjalankannya) }\end{array}$ & 4 & 4 \\
\hline 4. & $\begin{array}{l}\text { Jumlah tenaga (guru) yang } \\
\text { dibutuhkan } \\
\text { menjalankan aplikasi edu- } \\
\text { game profesi cukup satu guru }\end{array}$ & 4 & 3 \\
\hline 5. & $\begin{array}{l}\text { Tingkat kejelasan dalam } \\
\text { menjalankan aplikasi edu- } \\
\text { game profesi }\end{array}$ & 4 & 4 \\
\hline 6. & $\begin{array}{l}\text { Mendorong tumbuhnya minat } \\
\text { karier siswa PAUD terhadap } \\
\text { berbagai bidang profesi dalam } \\
\text { aplikasi edu-game profesi. }\end{array}$ & 3 & 3 \\
\hline 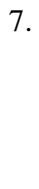 & $\begin{array}{l}\text { Aplikasi edu-game profesi } \\
\text { mendorong suasana belajar } \\
\text { yang menantang bagi guru } \\
\text { dan siswa PAUD dalam } \\
\text { mengenalkan bidang profesi }\end{array}$ & 4 & 4 \\
\hline 8. & $\begin{array}{l}\text { Kelayakan dalam } \\
\text { mengenalkan bidang profesi } \\
\text { sebagai upaya mengarahkan } \\
\text { minat karier siswa PAUD }\end{array}$ & 4 & 4 \\
\hline & Jumlah Skor & 31 & 30 \\
\hline & Rerata Skor & 3.875 & 3.75 \\
\hline & Kategori & $\begin{array}{r}\text { Sangat } \\
\text { layak }\end{array}$ & $\begin{array}{c}\text { Sangat } \\
\text { layak }\end{array}$ \\
\hline
\end{tabular}

Berdasarkan tabel 2 tersebut dapat dilihat bahwa penilaian kedua ahli tentang aspek kelayakan dari ini memberikan skor terhadap aplikasi edu-game profesi sangat tinggi, yaitu ahli 1 skor rata-rata adalah 3.875 dan ahli 2 memberi skor rata-rata 3.75 pada sebagian besar item pertanyaan yang diberikan pada aspek kelayakan. Menurut kriteria penilaian pada aspek kelayakan seperti ketentuan di atas, maka berdasarkan hasil penilaian ahli dengan skor rata-rata yang diperoleh umumnya mendekati 
skor 4 atau sangat layak. Dengan demikian disimpulkan bahwa aplikasi edu-game profesi ini termasuk dalam kriteria sangat layak untuk digunakan sebagai salah satu pilihan media pembelajaran pengenalan profesi yang menggunakan mobile handphone berbasis android.

\section{Aspek Ketepatan Aplikasi Edu-Game Profesi}

Indikator yang digunakan untuk menunjukan ketepatan aplikasi edu-game profesi adalah: ketepatan objek, ketepatan rumusan tujuan, dan ketepatan prosedur. Ketepatan obyek menyangkut ketepatan aplikasi edu-game profesi bila diterapkan pada siswa PAUD yang akan mengenal bidang profesi, ketepatan media pembelajaran yang digunakan dalam mengenalkan pembinaan bidang profesi, ketepatan menu-menu setiap game, dan petunjuk penggunaan setiap menu game serta ketepatan penggunaan aplikasi edugame profesi sebagai media mengenalkan bidang profesi pada siswa PAUD. Untuk keseluruhan diskriptor dalam indikator ketepatan obyek, kedua ahli menyatakan tepat.

Komponen ketepatan panduan selanjutnya adalah ketepatan rumusan tujuan dan petunjuk penggunaan aplikasi. Hasil penilaian ahli dalam melihat petunjuk penggunaan aplikasi ditinjau dari aspek ketepatan disajikan dalam Tabel 5.3 sebagai berikut.

Tabel 3. Penilaian Ahli tentang aspek Ketepatan Aplikasi Edu-Game Profesi

\begin{tabular}{llcc}
\hline \multirow{2}{*}{ Butir Pertanyaan } & \multicolumn{2}{c}{ Penilaian } \\
\cline { 2 - 3 } & & Ahli 1 & Ahli 2 \\
\hline 1. Kejelasan tujuan setiap & 4 & 4 \\
menu game yang & & \\
dimuat dalam buku & & \\
panduan edu-game \\
profesi
\end{tabular}

2. Kejelasan operasional penggunaan aplikasi pada setiap menu game

3. Kejelasan isi materi edu-game profesi terhadap bidang profesi yang diperkenalkan

4. Aplikasi edu-game 4
profesi membutuhkan
media penunjang

5. Aplikasi edu-game $3 \quad 3$ profesi memenuhi gambar-gambar yang dapat memotivasi minat belajar siswa.

6. Tingkat kejelasan pemilihan jenis huruf pada setiap game

7. Tingkat kejelasan warna setiap bidang profesi sesuai dengan gambar bidang profesinya

8. Tingkat kejelasan 3 tugas/latihan yang dimuat dalam setiap game

\begin{tabular}{lcc}
\hline Jumlah Skor & 28 & 28 \\
\hline Rerata Skor & 3.5 & 3.5 \\
\hline Kategori & $\begin{array}{c}\text { Sangat } \\
\text { tepat }\end{array}$ & $\begin{array}{c}\text { Sangat } \\
\text { tepat }\end{array}$ \\
\hline
\end{tabular}

Tabel 3 tersebut memperlihatkan bahwa kedua ahli memberikan penilaian pada aspek ketepatan dari aplikasi edu-game profesi ini dengan skor yang cukup tinggi, yaitu kedua ahli (ahli 1 dan ahli 2) memberi skor rata-rata 3.5 pada keseluruhan item pertanyaan yang diberikan pada aspek ketepatan. Menurut kriteria penilaian pada aspek ketepatan seperti terlihat pada 5.3 diatas, dapat disimpulkan bahwa rasa ingin tahu siswa PAUD terhadap berbagai bidang profesi dikategorikan tinggi. Dengan kata lain, bahwa aplikasi edu-game profesi sebagai media pembelajaran yang mengenalkan bidang profesi pada siswa PAUD adalah sangat tepat bagi anak dengan karakteristik cara belajar yang sesuai dengan usia siswa PAUD. Artinya substansi dari aplikasi edu-game yang dikembangkan memenuhi kriteria yang sangat tepat, sehingga dapat dikembangkan lebih lanjut.

Secara umum penilaian dari dua orang ahli terhadap aplikasi edu-game profesi cukup baik, artinya aplikasi ini layak digunakan. Hal ini terlihat dari sebaran nilai dari ketiga kriteria yang dibuat yaitu dari segi kegunaan, kelayakan, dan ketepatan, dimana skornya rata-rata berada pada level 4 dan 3. Dapat disimpulkan bahwa 
aplikasi edu-game profesi ini acceptable (dapat diterima), dan karena itu dapat digunakan sebagai salah satu alternatif pilihan media pembelajaran yang menyenangkan dan menantang bagi siswa PAUD dalam mengenalkan bidang profesi.

Data hasil diskusi subjek coba perorangan dimaksudkan untuk mengetahui keberterimaan panduan bagi guru PAUD. Dari diskusi antara peneliti yang bertindak sebagai fasilitator dan guru PAUD sebagai subjek penilaian kelompok perorangan, diperoleh data balikan sebagai berikut: a) secara umum materi dalam aplikasi sudah jelas dan dapat dipahami oleh guru untuk dikenalkan pada siswa PAUD, karena berisi bahan-bahan pengetahuan tentang berbagai jenis profesi yang dikemas dalam permainan yang menyenangkan; b) Jenis game dan pilihan profesi cukup tersdia jumlahnya, sesuai dengan tingkat dan karakteristik belajar siswa PAUD. Pilihan bidang profesi sudah sesuai dengan profesi yang dekat dan dikenal siswa PAUD dalam kehidupan sehari-hari, seperti polisi, dokter, pilot. Pilihan profesi yang dicontohkan cukup mewakili; c) Materi cukup menarik dan banyak gambar-gambar yang ditampilkan, sehingga menarik perhatian siswa PAUD.

Data hasil pengamatan pengenalan profesi menggunakan aplikasi edu-game profesi yang dilakukan oleh guru terhadap siswa PAUD menunjukkan suasana belajar yang menyenangkan. Pengamatan dilakukan terhadap 20 orang siswa dengan fokus pengamatan: 1) minat mengikuti edu-game profesi, 2) motivasi mengikuti edu-game profesi, 3) kesenangan mengikuti instruksi guru, 4) kemudahan dalam mengerjakan edu-game profesi, 5) kesukaan terhadap permainan aplikasi edu-game profesi, dan 6) kesan ingatan terhadap bidang profesi.

Data Tabel 4 menunjukkan hasil obesrvasi terhadap suasana belajar siswa PAUD pada saat pengenalan profesi oleh guru PAUD menggunakan aplikasi edu-game profesi. Data menunjukkan bahwa kondisi belajar siswa PAUD menunjukkan skor yang tinggi mendekata skor rata-rata 4 , yaitu skor rata-rata minat $=3.8$, skor rata-rata motivasi $=3.75$, skor rata-rata kesenangan $=3.8$, skor rata-rata kemudahan $=3.8$, skor rata-rata kesukaan $=3.8$, dan skor rata-rata kesan ingatan $=3.5$.

Berdasarkan data tersebut, maka diperoleh informasi bahwa siswa PAUD dari hasil pengamatan umumnya menunjukkan: 1) minat belajar yang sangat tinggi dalam mengenal profesi, 2) motivasi belajar yang sangat tinggi dalam mengenal profesi, 3) suasana belajar yang bersifat senang dalam mengenal profesi, 4) kemudan belajar dalam mengenal profesi, 5) kesukaan belajar yang tinggi dalam mengenal profesi, dan 6) ingatan yang cukup kuat terhadap bidang profesi yang dipelajari.

Tingginya minat, motivasi, dan suasana kesenangan belajar mengenal profesi oleh siswa menunjukkan sikap penerimaan siswa terhadap aplikasi ini. Dengan demikian aplikasi edu-game profesi memenuhi kriteria yang layak, tepat dan berguna bagi siswa PAUD dalam mengenal profesi. Keberterimaan ini menunjukkan bahwa aplikasi ini efektif digunakan dalam membelajarkan pengenalan profesi pada siswa PAUD dengan menggunakan media belajar mobile learning berbasis handphone android.

Keberterimaan aplikasi dalam penilaian ahli materi dan ahli media pembelajarn adalah karena pembelajaran abad sekarang menghendaki adanya inovasi media pembelajaran yang memanfaatkan mobile learning sebagai salah satu ciri pembelajaran era teknologi informasi. Menurut O' Malley (2003), mobile learning merupakan suatu pembelajaran yang terjadi ketika pembelajar memanfaatkan perangkat teknologi yang bergerak. Aplikasi edu-game merupakan perangkat teknologi informasi dengan menu game yang bergerak, dan memungkinkan untuk dijalankan. Terrel (2011) menegaskan bahwa salah satu ciri dari mobile learning adalah memiliki menu yang dapat dipilih dan dipelajari sendiri oleh pengguna.

Menjalankan edu-game profesi serasa seperti berselancar diarea permainan yang menantang dan memberikan informasi makna dari setiap permaianan yang dijalankan. Seperti pada permainan mencari perbedaan pada satu bidang profesi tertentu yang sesungguhnya makna dibalik perbedaan tersebut adalah mengandung informasi yang kuat dari ciri profesi yang sebenarnya yang melekat pada atribut yang dikenakan. Atribut yang dapat dibedakan oleh siswa PAUD dalam permainan menunjukkan ingatan yang kuat terhadap bidang profesi yang diidentifikasi.

Pengembangan game sebagaimana layaknya yang diharapkan untuk tujuan edukasi sedapat mungkin dibuat sesuai dengan kebutuhan individu dari pembelajar, mengurangi kecenderungan ketidak tahuan anak, memfasilitasi situasi lingkungan belajar aktif yang membangkitkan rasa ingin tahu, dan memungkinkan terjadinya proses belajar scaffolding (Foreman, 2004). Penjelasan ini 
menegaskan betapa perlunya menyediakan perangkat pembelajaran bagi anak PAUD sebagai upaya memfasilitasi minat dan keingintahun akan dalam mengidentifikasi konsep dalam kerangka tumbuh kembang anak sebagai individu yang sedang belajar.

Tabel 4. Penilaian Pengguna Produk Kelompok Siswa terhadap Kondisi Belajar

\begin{tabular}{|c|c|c|c|c|c|c|c|}
\hline No & Responden Siswa & $\begin{array}{l}\text { minat } \\
\text { mengikuti } \\
\text { edu-game } \\
\text { profesi }\end{array}$ & $\begin{array}{l}\text { motivasi } \\
\text { mengikuti } \\
\text { edu-game } \\
\text { profesi }\end{array}$ & $\begin{array}{l}\text { kesenangan } \\
\text { mengikuti } \\
\text { instruksi } \\
\text { guru }\end{array}$ & $\begin{array}{l}\text { kemudahan } \\
\text { dalam } \\
\text { mengerjakan } \\
\text { edu-game } \\
\text { profesi }\end{array}$ & $\begin{array}{l}\text { kesukaan } \\
\text { terhadap } \\
\text { permainan } \\
\text { aplikasi edu- } \\
\text { game profesi }\end{array}$ & $\begin{array}{l}\text { kesan } \\
\text { ingatan } \\
\text { terhadap } \\
\text { bidang } \\
\text { profesi } \\
\end{array}$ \\
\hline 1 & Siswa 1 & 4 & 4 & 4 & 4 & 4 & 3 \\
\hline 2 & Siswa 2 & 4 & 3 & 4 & 4 & 4 & 4 \\
\hline 3 & Siswa 3 & 3 & 3 & 3 & 3 & 3 & 3 \\
\hline 4 & Siswa 4 & 4 & 4 & 4 & 4 & 4 & 4 \\
\hline 5 & Siswa 5 & 3 & 3 & 3 & 3 & 3 & 3 \\
\hline 6 & Siswa 6 & 4 & 4 & 4 & 4 & 4 & 4 \\
\hline 7 & Siswa 7 & 4 & 4 & 4 & 4 & 4 & 3 \\
\hline 8 & Siswa 8 & 4 & 4 & 4 & 4 & 4 & 4 \\
\hline 9 & Siswa 9 & 4 & 4 & 4 & 4 & 4 & 3 \\
\hline 10 & Siswa 10 & 4 & 4 & 4 & 4 & 4 & 4 \\
\hline 11 & Siswa 11 & 4 & 4 & 4 & 4 & 4 & 3 \\
\hline 12 & Siswa 12 & 4 & 4 & 4 & 4 & 4 & 4 \\
\hline 13 & Siswa 13 & 4 & 4 & 4 & 4 & 4 & 4 \\
\hline 14 & Siswa 14 & 3 & 3 & 3 & 3 & 3 & 3 \\
\hline 15 & Siswa 15 & 4 & 4 & 4 & 4 & 4 & 4 \\
\hline 16 & Siswa 16 & 4 & 4 & 4 & 4 & 4 & 3 \\
\hline 17 & Siswa 17 & 4 & 4 & 4 & 4 & 4 & 4 \\
\hline 18 & Siswa 18 & 3 & 3 & 3 & 3 & 3 & 3 \\
\hline 19 & Siswa 19 & 4 & 4 & 4 & 4 & 4 & 4 \\
\hline 20 & Siswa 20 & 4 & 4 & 4 & 4 & 4 & 3 \\
\hline \multicolumn{2}{|c|}{ Jumlah Skor } & 76 & 75 & 76 & 76 & 76 & 70 \\
\hline \multicolumn{2}{|c|}{ Skor rata-rata } & 3.8 & 3.75 & 3.8 & 3.8 & 3.8 & 3.5 \\
\hline \multicolumn{2}{|c|}{ Kategori } & $\begin{array}{c}\begin{array}{c}\text { Sangat } \\
\text { berminat }\end{array} \\
\text { ber }\end{array}$ & $\begin{array}{c}\text { Sangat } \\
\text { termotivasi }\end{array}$ & $\begin{array}{l}\text { Sangat } \\
\text { senang }\end{array}$ & $\begin{array}{l}\text { Sangat } \\
\text { mudah }\end{array}$ & Sangat suka & $\begin{array}{c}\text { Sangat } \\
\text { berkesan }\end{array}$ \\
\hline
\end{tabular}

\section{SIMPULAN DAN SARAN}

Berdasarkan tujuan penelitian yang diajukan dalam penelitian ini, dari laporan sementara yang diperoleh sebagai bagian dari kemajuan penelitian, dapat disimpulkan bahwa: a) Telah diperoleh aplikasi edu-game profesi yang memenuhi kriteria kebergunaan, ketepatan, dan kelayakan. Ahli materi PAUD dan ahli media pembelajaran memberi respon positif bahwa aplikasi edu-game profesi dapat digunakan sebagai media pembelajaran mengenal profesi; $b$ ) Telah diperoleh hasil uji coba pengguna produk (guru PAUD) yang menujukkan respon positif bahwa aplikasi edu-game profesi telah memenuhi kriteria berguna, layak, dan tepat. Sehingga aplikasi edu-game profesi dapat digunakan sebagai pilihan media pembelajaran menggunakan perangkat mobile learning; c)
Telah diperoleh hasil pengamatan belajar mengenal bidang profesi pada siswa PAUD yang menunjukkan bahwa siswa PAUD telah menunjukkan suasana

Berdasaran temuan peneltan maka disarankan agar penelitian masih berlanjut dengan fokus pada perbaikan finalisasi panduan materi edu-game profesi, dan finalisasi instalasi pada android. Rancangan prototipe aplikasi sebelum dimasukkan dalam versi android, terlebih dahulu dilakukan uji operasi dalam bentuk APK. Sehingga diharapkan produk dapat lebih baik sesuai dengan karakteristik guru PAUD dan siswa PAUD.

\section{DAFTAR RUJUKAN}

Ally, Muhamed. (2009). Mobile learning: transforming the delivery of education and training. Québec: AU Press 
Borg., Walter R \& Gall, D. Meredith. (2003). Education Research:an Introduction. (7 $7^{\text {th }}$ Edition). Allyn Bacon

Clark, Donald. (2006). Games and e-learning: www.caspianlearning.co.uk/Whtpcaspiangames_1.1.pdf. Diakses tanggal $20 \mathrm{Mei}$ 2016.

Darmawan, Deni. (2012). Teknologi Pembelajaran. Bandung: Remaja Rosdakarya

Foreman, J.G. (2004). Game Based Learning: How to delight and instruct in the 12 st century. Educause Review.

Gustafson Kent L., \& Branch, Robert M. (2002). Survey of instructional development models (4 ${ }^{\text {th }}$ ed.). Syracuse, NY: ERIC Clearinghouse on Information \& Technology, Syracuse University

Hamari, J., Shernoff, JD., Rowe, E., Coller, B., Clarke, AJ., Edwars, T. (2016). Challenging Games Help Students Learn: an Empirical Study on Engagement, Flow and Immersion in Game-Based Learning. Computers in Human Behavior 54 (2016) 170-179.

Istiyanto, Jazi Eko. (2013). Pemrograman Smartphone Menggunakan SDK Android dan Hacking Android. Yogyakarta: Graha Ilmu

Nilwan, Agustinus. (2009). Pemrograman Animasi dan Game Profesional, Elex Media Komputindo, Jakarta.
O'Malley,C, dkk. (2003). Guidelines For Learning/Teaching/Tutoring in a Mobile Environtment (Online), (http://www.mobilearn.org/download/resu lts/guidelines.pdf, diakses pada 29 Agustus 2018)

Safaat, Nazrudin. (2012). Pemrograman Aplikasi Mobile Smartphone dan Tablet PC Berbasis Android. Bandung: Informatik

Santrock, JohnW, (2002). Life Span Development , Jakarta:Penerbit Erlangga

Simatupang, Hayati Nut. (2005). Bermain Sebagai Upaya Dini Menanamkan Aspek Sosial Bagi Siswa Sekolah Dasar. Jurnal Pendidikan Jasmani Indonesia. Volume 3. No. 1. Hal. 23-31.

Terrel, Shelly Sanchez. (2011). Effective Mobile Learning, 50 + Quick Tips \& Resources, (Online), (http://www.scribd.com/doc/67369598/Ef fective-Mobile-Learning-50-Tips-

Resources-Ebook, diakses pada 26 Agustus 2018)

Woodill, G. (2010). The mobile learning edge: Tools and technologies for developing your teams. McGraw Hill Professio

Yatmo, Bangkit Tri. (2013). Game Aplikasi Pembelajaran Penulisan Aksara Jawa "Hanacara" Berbasis Android. Skripsi. Sekolah Tinggi Manajemen Informatika dan Komputer. Amikom: Yogyakarta 